\title{
Distribution and Preliminary Exposure Assessment of Bisphenol AF (BPAF) in Various Environmental Matrices around a Manufacturing Plant in China
}

\author{
Shanjun Song, Ting Ruan, Thanh Wang, Runzeng Liu, and Guibin Jiang*
}

State Key Laboratory of Environmental Chemistry and Ecotoxicology, Research Center for Eco-Environmental Sciences, Chinese Academy of Sciences, Beijing 100085

\section{Supporting Information}

ABSTRACT: Increasing attention has been paid to bisphenol $A$ and bisphenol (BP) analogues due to high production volumes, wide usage and potential adverse effects. Bisphenol $\mathrm{AF}$ (BPAF) is considered a new bisphenol analogue which is used as raw material in plastic industry, but little is known about its occurrence in the environment and the potential associated risk. In this work, BPAF levels and environmental distribution were reported in samples collected around a manufacturing plant and a preliminary exposure risk assess-

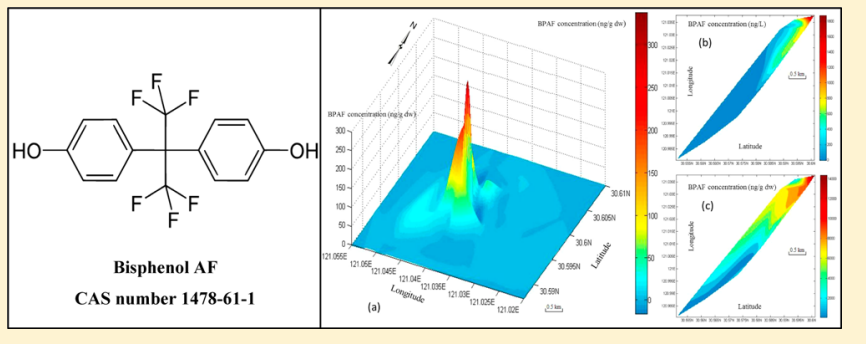
ment to local residents was conducted. BPAF was detected in most of the samples, with levels in river ranging between $<$ LOD to $1.53 \times 10^{4} \mathrm{ng} / \mathrm{L}$, sediments $\left(0.520-2.00 \times 10^{3} \mathrm{ng} / \mathrm{g} \mathrm{dry}\right.$ weight, $\mathrm{dw}$ ), soils $(<\mathrm{LOD}$ to $331 \mathrm{ng} / \mathrm{g} \mathrm{dw})$ and indoor dusts $(7.82-739 \mathrm{ng} / \mathrm{g} \mathrm{dw})$ and well water $(<\mathrm{LOD}$ to $300 \mathrm{ng} / \mathrm{L})$. Exponential declining trends were observed for BPAF levels with increasing distance from the manufacturing plant. Based on the quantitative data and quantitative structure-property relationship (QSPR) model deduction, BPAF was predicted to mainly retain in sediment and soil after released into the ambient environment and organic carbon was the domain factor during the process. The preliminary BPAF exposure assessment based on the CSOIL model suggested that children could have higher intake of BPAF than adults through inhalation of soils, dermal exposure by soils contact and bathing with well water.

\section{INTRODUCTION}

Bisphenols (BPs) are a group of chemicals containing two phenolic rings bridged by a carbon group, which have wide applications in the plastic and organic synthesis industry such as raw material in the manufacture of plastics, fire-resistant polymers, resin lining of food and beverage cans, dentistry sealants, and thermal paper. ${ }^{1}$ There are currently increasing concerns about BPs as a result of their widespread distribution in various environmental compartments and potential adverse effects to biota and humans. Certain BPs, such as bisphenol A (BPA), bisphenol B (BPB), bisphenol F (BPF), bisphenol S (BPS), and bisphenol AF (BPAF) have already been proven to have endocrine disrupting effects. ${ }^{2-4}$ For example, BPA could increase human MCF-7 breast cancer cell numbers in a dosedependent manner during in vitro exposure at concentrations from $10^{-7}$ to $10^{-5} \mathrm{M}^{5}$ Furthermore, BPA, BPB, and BPAF were also identified as agonists of human pregnane $\mathrm{X}$ receptor (PXR), which is a nuclear receptor functioning as a master regulator of xenobiotic metabolism. ${ }^{6}$ BPF have shown significant genotoxic in HepG2 cells (human hepatoma cell line) while BPS also exhibited similar genotoxicity and estrogenic activity to $\mathrm{BPA}^{7}$ Particular public interests have also been focused on the potential health impact and exposure risk assessments on these estrogenic xenobiotics. ${ }^{8}$ However, despite their extensive usage in industry and commercial applications, there is still a lack of knowledge about the release patterns and environmental occurrence of some of the BPs, which is essential to better estimate potential exposure routes to human. Current monitoring studies mostly focus on a small fraction of BP analogues, mainly on BPA which is the dominant $\mathrm{BP}$ and is utilized as a monomer in the production of polycarbonate plastics and epoxy resins. ${ }^{9}$ It has been found to be ubiquitously present in the environment, biota, and even humans. ${ }^{10}$ Its endocrine disrupting effects and pervasive exposure to humans through, for example, dermal contact, inhalation and diet, ${ }^{11-13}$ has led to consideration for stricter regulations on the production and usage of BPA in countries and regions such as North America, European Union, and China. ${ }^{4-16}$ As a result, other BP analogues could be introduced into the market as alternatives in certain products for similar application and purposes. Currently, among the BPs, $\mathrm{BPF}$ has been found in canned beverages and filling liquids of canned vegetables, and also detected in surface water in Germany with concentrations ranging from 100 to $1.80 \times 10^{5}$ $\mathrm{ng} / \mathrm{L}^{17,18} \mathrm{BPB}$ residues were identified in canned peeled tomatoes and beverages in several European countries. ${ }^{19,20} \mathrm{BPB}$ has also been found in human blood sera ranging from 880 to

Received: September 29, 2012

Revised: November 12, 2012

Accepted: November 14, 2012

Published: November 14, 2012 


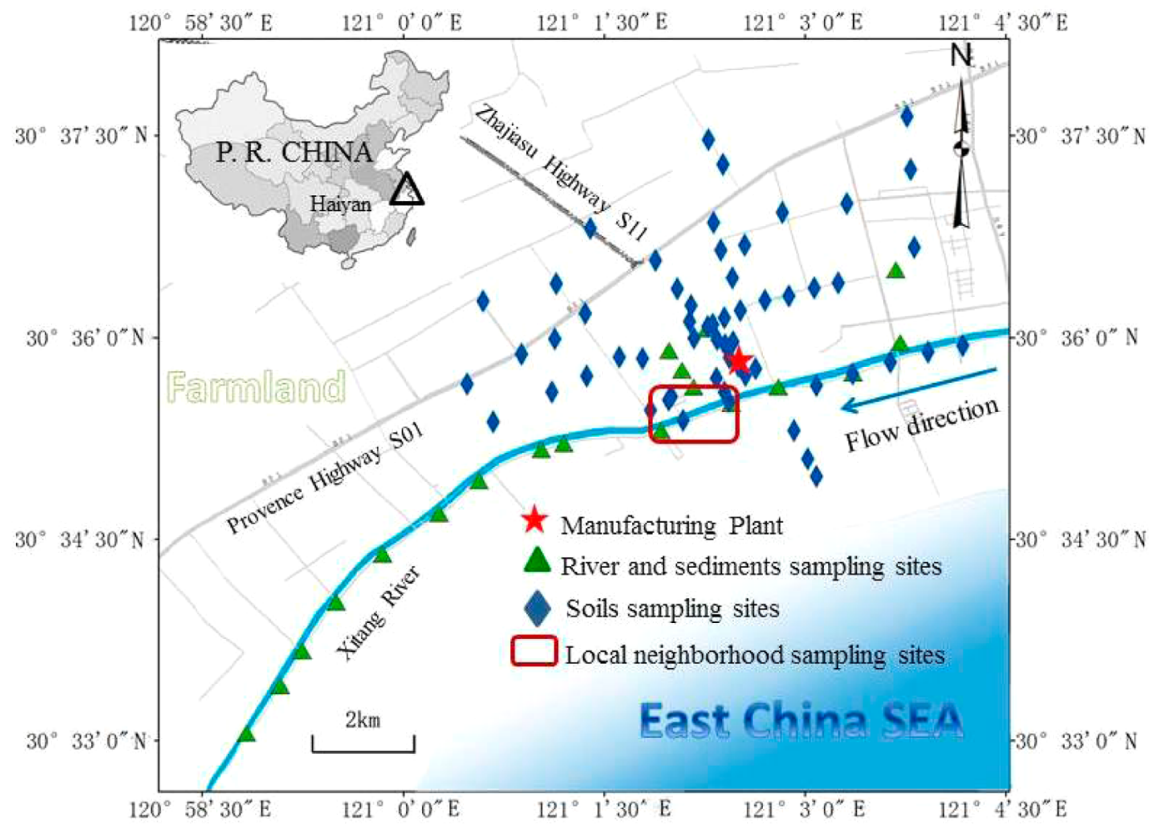

Figure 1. Sampling sites around a BPAF manufacturing plant. (Red pentacle: BPAF manufacturing plant, green triangle: sampling sites for river water and sediment samples, blue tetragon: sampling sites for soil samples, red box: local residential neighborhood collection area, Blue arrow: flow direction of the river. The latitudes of the investigated region ranged from $30^{\circ} 33^{\prime} 0^{\prime \prime} \mathrm{N}$ to $30^{\circ} 37^{\prime} 30^{\prime \prime} \mathrm{N}$ and the longitudes from $120^{\circ} 50^{\prime} 30^{\prime \prime} \mathrm{E}$ to $121^{\circ} 04^{\prime} 30^{\prime \prime} \mathrm{E}$.).

$1.19 \times 10^{4} \mathrm{ng} / \mathrm{L}$ and its levels in urine have been reported to be at several micrograms per liter. ${ }^{21,22}$ BPS was found in human urine and paper products such as thermal receipts and paper currencies, which were estimated to be potentially one of the major sources of human exposure. ${ }^{23,24}$ Recently, BPS and BPF were detected as main BP components along with BPA with concentrations in the range of $0.83-2.66 \times 10^{4} \mathrm{ng} / \mathrm{g}$ and below the limit of quantitation (LOQ) to $1.07 \times 10^{5} \mathrm{ng} / \mathrm{g}$ in indoor dusts from U.S. and several Asian countries. ${ }^{13}$ As already partially replacing BPA in the industrial applications, the production of certain BPs such as BPS and BPAF are perceived to be increasing in recent years. ${ }^{23,25}$

The structural difference between BPA and BPAF is that the methyl groups bound to the central bridging carbon atom has been replaced by $\mathrm{CF}_{3}$ groups. This is to further improve the thermal and chemical stability. It has been reported to be used as a cross-linker in fluoroelastomers, electronics and optical fibers, ${ }^{25,26}$ and also acts as a high-performance monomer for polyimides, polyamides, polyesters, polycarbonate copolymers and other specialty polymers which can be found in daily use products. ${ }^{27}$ The domestic annual production of BPAF in the U.S. was reported to range from 10000 to 500000 pounds between 1986 and 2002, which is considered as a moderate production volume chemical. ${ }^{28}$ Although research literatures have mainly reported on the BPAF synthesis methods and its industrial applications, ${ }^{25,29}$ recent studies have also focused on the potential toxic effects of BPAF both in vivo and in vitro. ${ }^{30,31}$ It was found that BPAF exhibits a stronger binding ability than $\mathrm{BPA}$ on estrogen receptor $\mathrm{ER} \alpha$ and functions as an antagonist on ER- $\beta$ receptor. ${ }^{32}$ Results from in vivo exposure experiments on male Sprague-Dawley (SD) rats also showed that BPAF may cause reduction of the expression of steroidogenic genes, which play key roles in cholesterol transport and steroid biosynthesis, and result in the decrease of testosterone production. $^{33}$
The current BPAF production volume worldwide is unknown and very limited data are available about its potential environmental distribution and fate. In this work, an analytical method employing liquid chromatography tandem triplequadrupole mass spectrometry (HPLC-MS/MS) was established. Environmental samples near a BPAF manufacturing plant in China were collected and analyzed to provide information for understanding the environmental levels, transport and potential bioaccumulation of BPAF. On the basis of the obtained results, preliminary exposure risk estimates for nearby local residents were also conducted.

\section{MATERIALS AND METHODS}

Chemicals and Standards. Bisphenol AF (CAS No. 1478-61-1; purity 99\%) was purchased from TCI (Portland, OR). Isotope-labeled bisphenol A (rings- ${ }^{13} \mathrm{C}$; purity 99\%) and ${ }^{13} \mathrm{C}$-tetrabromobisphenol A (rings- ${ }^{13} \mathrm{C}$; purity 99\%) were obtained from Cambridge (Andover, MA). Solid phase extraction columns used were Sep-Pak C18 cartridges ( $1 \mathrm{~g}, 6$ cc) from Waters Corporation (Milford, MA). Ultrapure water was prepared by a Milli-Q system (Millipore, MA). HPLC grade methanol and dichloromethane (DCM) were obtained from JT Baker (Center Valley, PA).

Sample Collection. All soil, river water and sediment samples were collected around a manufacturing plant in Jiaxing city, Zhejiang province in Southeast China. Detailed information of the sampling map and sites is shown in Figure 1. This plant has an annual production capacity of about $100 \mathrm{t}$ and it is reported to be one of the largest manufacturers of BPAF in China. ${ }^{34}$ Sampling was conducted both in an industrial park where the plant is located and at a residential area situated southwest from the plant. A total of 68 soil samples were collected at a spatial distance from 0 to $7 \mathrm{~km}$ around the plant. All soil samples were collected at the top $0-20 \mathrm{~cm}$ surface layer with a stainless steel scoop. At each site, five separate soil samples were collected and mixed thoroughly to obtain one 
composite sample. Soils were immediately packed in aluminum foil and freeze-dried once transported back to the laboratory.

Three upstream water samples and 13 paired downstream water and sediment samples were collected along with the recipient river nearby the industrial park. At each site, $500 \mathrm{~mL}$ water was collected in triplicate using stainless steel buckets and stored in brown glass bottles. All vessels were precleaned with methanol to avoid cross-contamination. Sediments were collected using a stainless steel grab sampler concurrently with each water sample (glass bottles) at downstream locations. All sediment samples were wrapped in aluminum foil, placed in zipper bags and transported back to the laboratory and stored in $-20{ }^{\circ} \mathrm{C}$ until pretreatment.

Additional samples, including 17 indoor dust, 12 tap, and 12 well water samples were collected from randomly selected families in the local residential area about $0.5 \mathrm{~km}$ away from the manufacturing plant (Figure 1). Indoor dust samples were directly collected from the ground and sieved through a 0.15 $\mathrm{mm}$ sieve to remove hair, paper scraps, and other unwanted materials. Well and tap water samples were contained in glass bottles and sealed tightly.

Sample Pretreatment. Solid phase extraction (SPE) was optimized as the primary extraction and cleaning procedure for all water samples. Before SPE, $200 \mathrm{~mL}$ water sample was spiked with $20 \mathrm{ng}{ }^{13} \mathrm{C}$-bisphenol $\mathrm{A}$ as surrogate standard, and then filtered with a $0.7 \mu \mathrm{m}$ glass fiber membrane. After preconditioned by $6 \mathrm{~mL}$ methanol and $10 \mathrm{~mL}$ purified water, $200 \mathrm{~mL}$ of sample was loaded onto the Sep-pak C18 cartridge at a rate of $5 \mathrm{~mL} / \mathrm{min}$, and the cartridges were subsequently eluted with $6 \mathrm{~mL}$ methanol. The elution was then concentrated to $1 \mathrm{~mL}$ by gentle $\mathrm{N}_{2}$ stream with $50 \mathrm{ng}{ }^{13} \mathrm{C}$-Tetrabromobisphenol A added to each sample as internal standard before instrumental analysis.

Soil, sediment, and dust samples were freeze-dried and grinded to particles smaller than 100-mesh. An aliquot of $1 \mathrm{~g}$ sample was extracted by accelerated solvent extraction (ASE, ASE 300, Dionex) using methanol as solvent at $170{ }^{\circ} \mathrm{C}$ and 1500 psi for 3 cycles. Afterward, the extract was concentrated by rotary evaporation to about $2 \mathrm{~mL}$ for further cleanup procedure. To minimize potential matrix effects in the extracts, a column packed with different layers consisting of $6 \mathrm{~g}$ silica gel, $6 \mathrm{~g} \mathrm{Al}_{2} \mathrm{O}_{3}$, and $3 \mathrm{~g} \mathrm{Na}_{2} \mathrm{SO}_{4}$ from bottom to the top was utilized as cleanup process instead of SPE. Silica gel was preheated at $150{ }^{\circ} \mathrm{C}$ for $12 \mathrm{~h}$, while $\mathrm{Al}_{2} \mathrm{O}_{3}$ was baked at $450{ }^{\circ} \mathrm{C}$ for $8 \mathrm{~h}$. Both adsorbents were $5 \%$ water-deactivated prior to use. The column was prewashed by $30 \mathrm{~mL}$ hexane and $30 \mathrm{~mL}$ hexane/ dichloromethane $(1: 1, \mathrm{v} / \mathrm{v})$ in sequence. After sample loading, $60 \mathrm{~mL}$ hexane/dichloromethane mixture $(1: 1, \mathrm{v} / \mathrm{v})$ of eluted fraction was collected. The elution was then concentrated to 2 $\mathrm{mL}$ and was finally substituted with $1 \mathrm{~mL}$ methanol by gentle $\mathrm{N}_{2}$ stream prior to instrument analysis.

Instrument Analysis. A Waters 2695 Alliance Separations Module HPLC System equipped with a Symmetry Shield RP18 analytical column $(4.6 \times 150 \mathrm{~mm}, 5 \mu \mathrm{m}$, Waters $)$ was used for analyte separation. Methanol (A) and water (B) were selected as the mobile phases. The flow gradient program was initially at 50: 50 (A: B), then gradually ramped to 70: 30 (A: B) in 10 $\mathrm{min}$, and to $100 \% \mathrm{~A}$ in $3 \mathrm{~min}$. The flow rate was $1 \mathrm{~mL} / \mathrm{min}$ with $\mathrm{BPAF}$, eluted at $13 \mathrm{~min}$. Injection volume was set at $20 \mu \mathrm{L}$.

A Quattro Ultima triple quadrupole mass spectrometer (Waters, Milford, MA) was employed for quantitative analysis. The atmospheric pressure chemical ionization (APCI) source was operated at negative ion mode. Details on the instrumental parameters are summarized as follows: corona current: $5.0 \mu \mathrm{A}$; cone voltage: $45 \mathrm{~V}$; source temperature: $110^{\circ} \mathrm{C}$; APCI probe temperature: $300{ }^{\circ} \mathrm{C}$; cone gas flow: $100 \mathrm{~L} / \mathrm{h}$; desolvation gas flow: $350 \mathrm{~L} / \mathrm{h}$. Multiple reaction monitoring (MRM) mode was used with a dwell time of $100 \mathrm{~ms}$ and the collision energy was optimized at $20 \mathrm{eV}$. According to mass scan result, ion pairs of $334.7>265\left([\mathrm{M}-2 \mathrm{H}]-\mathrm{CF}_{3}\right)$ were selected as quantification ions and $334.7>197\left(\left[\mathrm{M}-2 \mathrm{H}-\mathrm{CF}_{3}-\mathrm{CF}_{3}\right)\right.$ were used as confirmation transition ions.

Quality Assurance/Quality Control. To ensure the positive identification and quantitation procedure of BPAF, three quality control criteria ${ }^{35}$ were applied: LC retention time should match that of the standard within $0.5 \mathrm{~min}$; signal-tonoise ratio $(\mathrm{S} / \mathrm{N})$ greater than 10:1 was required for positive quantitation; the isotopic ratios for selected ion pairs were within $15 \%$ of the theoretical values. For each batch of 16 samples, a procedural blank consisting of purified water or uncontaminated soil sample was added, and the results showed no contamination occurred during the pretreatment process. Spiked water samples $\left(n=5,50 \mathrm{ng}{ }^{13} \mathrm{C}\right.$-bisphenol A, $50 \mathrm{ng}$ BPAF) showed no significant differences between BFAF ( $88 \pm$ $2 \%)$ and ${ }^{13}$ C-bisphenol A $(94 \pm 4 \%)$ recoveries. Similar results were also observed for spiked soil, sediment and indoor dust samples $\left(n=5,50 \mathrm{ng}{ }^{13} \mathrm{C}\right.$-bisphenol A, $\left.50 \mathrm{ng} \mathrm{BPAF}\right)$ where $\mathrm{BFAF}$ and ${ }^{13} \mathrm{C}$-bisphenol recoveries were $72 \pm 7 \%$ and $71 \pm$ $10 \%$, respectively. The method limit of detection (MDL) was $1.5 \mathrm{ng} / \mathrm{L}$ for water, $0.5 \mathrm{ng} / \mathrm{g}$ dry weigh $(\mathrm{dw})$ for soil samples, $0.3 \mathrm{ng} / \mathrm{g} \mathrm{dw}$ for sediments and $0.2 \mathrm{ng} / \mathrm{g} \mathrm{dw}$ for indoor dust. A seven point standard curve was prepared at a range of $1-1000$ $\mu \mathrm{g} / \mathrm{L}$ and the calibration curve showed high linearity with $R^{2}>$ 0.99 .

Statistical Analysis. Data analyses were conducted using SPSS V17.0 for Windows Release (SPSS Inc., 2009) with statistical significance defined at $\alpha \leq 0.05$ levels. The BPAF concentration data in various environment matrixes were analyzed by using descriptive statistics, Pearson correlation coefficients, and least-squares linear regression fitting. Nondetects for soil samples within $2 \mathrm{~km}$ from the plant were treated as half MQL, and as zero at sites $>2 \mathrm{~km}$ during statistical analysis due to the very low detection frequency outside this range.

\section{RESULTS AND DISCUSSION}

Concentrations of BPAF in Various Environmental Matrices. All results are summarized in Table S1 (Supporting Information (SI)). Concentrations of BPAF in water samples along the river ranged from $\angle \mathrm{LOD}$ to $1.53 \times 10^{4} \mathrm{ng} / \mathrm{L}$ with a median value of $3.08 \times 10^{3} \mathrm{ng} / \mathrm{L}$. The levels in corresponding sediment samples ranged from 0.520 to $2.00 \times 10^{3} \mathrm{ng} / \mathrm{g} \mathrm{dw}$ with a median value of $169 \mathrm{ng} / \mathrm{g} \mathrm{dw}$, while soil samples contained levels in the range of <LOD to $331 \mathrm{ng} / \mathrm{g} \mathrm{dw}$ with a median concentration of $0.345 \mathrm{ng} / \mathrm{g} \mathrm{dw}$. Samples obtained from the local residential neighborhood were also detectable for BPAF, with indoor dust levels ranging from $15.5 \mathrm{ng} / \mathrm{g} \mathrm{dw}$ to $739 \mathrm{ng} / \mathrm{g} \mathrm{dw}$, with the median concentration $124 \mathrm{ng} / \mathrm{g} \mathrm{dw}$. Of the twelve well water samples, 11 were detected for BPAF with levels ranging from $<\mathrm{LOD}$ to $300 \mathrm{ng} / \mathrm{L}$ and a median value of $50.0 \mathrm{ng} / \mathrm{L}$. Only one of the twelve tap water samples was found to contain BPAF at a concentration of $40.0 \mathrm{ng} / \mathrm{L}$.

Distribution and Behavior in Surface Water. According to quantitative structure-activity relationship model deductions from Health Canada, the dissociation constant of BPAF is 8.11 which indicates that most of BPAF is in neutral form in 
natural water environment. ${ }^{36}$ Among the 16 water samples from the river which crosses the industrial zone, BPAF was detected in two of the samples from the upstream sites with concentrations of 80.0 and $40.0 \mathrm{ng} / \mathrm{L}$. However, BPAF was not detected at sites more than $1 \mathrm{~km}$ away from the plant in the upstream direction. At downstream sites, BPAF was detected in all 13 samples. The concentrations of BPAF at downstream locations ranged from 60.0 to $1.53 \times 10^{4} \mathrm{ng} / \mathrm{L}$. The concentration peaked at the site nearest to the wastewater outlet of the plant, which was about 190 times higher than the upstream site $500 \mathrm{~m}$ away from the plant. This strongly suggests that the manufacturing plant is the main BPAF source to the recipient river. The concentration rapidly decreased 3-5 folds at downstream within $3 \mathrm{~km}$, after which the concentration decline trend tended to slow down. The declining concentration trend with distance could be fitted with an exponential decay function, similar as previously reported for point source contaminations (Figure 2). ${ }^{37} \mathrm{~A}$ similar exponential declining

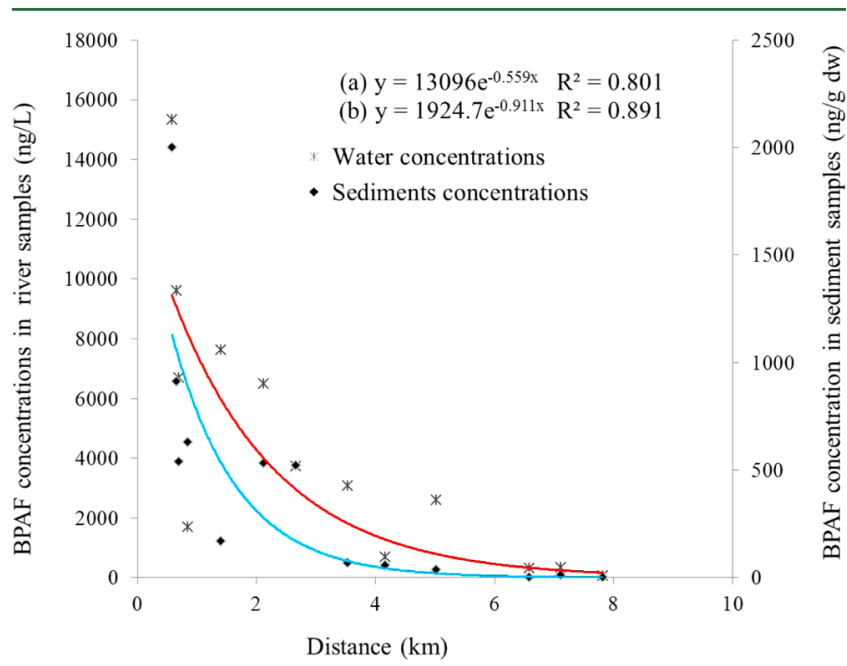

Figure 2. BPAF concentration vs distance from the manufacturing plant: (a) in river water and (b) in sediments.

trend with distance was also found for sediments (Figure 2), where the highest concentration was also found at the sampling site nearest to the manufacturing plant. For distant samples located from 3 to $8 \mathrm{~km}$, the concentrations $(0.52-68.4 \mathrm{ng} / \mathrm{g}$ $\mathrm{dw}$ ) were about 70 or more times lower than the initial concentration. Organic carbon is considered to play an important role in the distribution and transport of hydrophobic organic chemicals between water and sediment phases. ${ }^{38}$ When normalized to total organic carbon (TOC) content, the BPAF concentrations among the 13 sediment samples varied greatly with a range from 40.6 to $6.15 \times 10^{4} \mathrm{ng} / \mathrm{g}$ TOC and a median concentration of $1.29 \times 10^{4} \mathrm{ng} / \mathrm{g}$ TOC. To investigate the transfer efficiency between water and sediments, a correlation between sediment/water ratio and TOC content in sediments was conducted. A good linear relationship between BPAF concentrations in water and TOC normalized sediments was found $\left(R^{2}=0.86, p<0.01\right.$, Figure 3$)$. The distribution coefficient between sediment phase and water $\left(\log K_{\mathrm{oc}}\right)$ is generally used for describing the partitioning trends of a certain chemical and is obtained using eq $1 .{ }^{39}$ On the basis of field samples, $\log K_{\mathrm{oc}}$ of BPAF was calculated at an average value of $3.28 \pm 0.4(n=14)$. This value is quite similar with the model estimated value of $3.73 .^{36}$ This indicated that sediment could adsorb a considerable amount of BPAF, resulting in a high
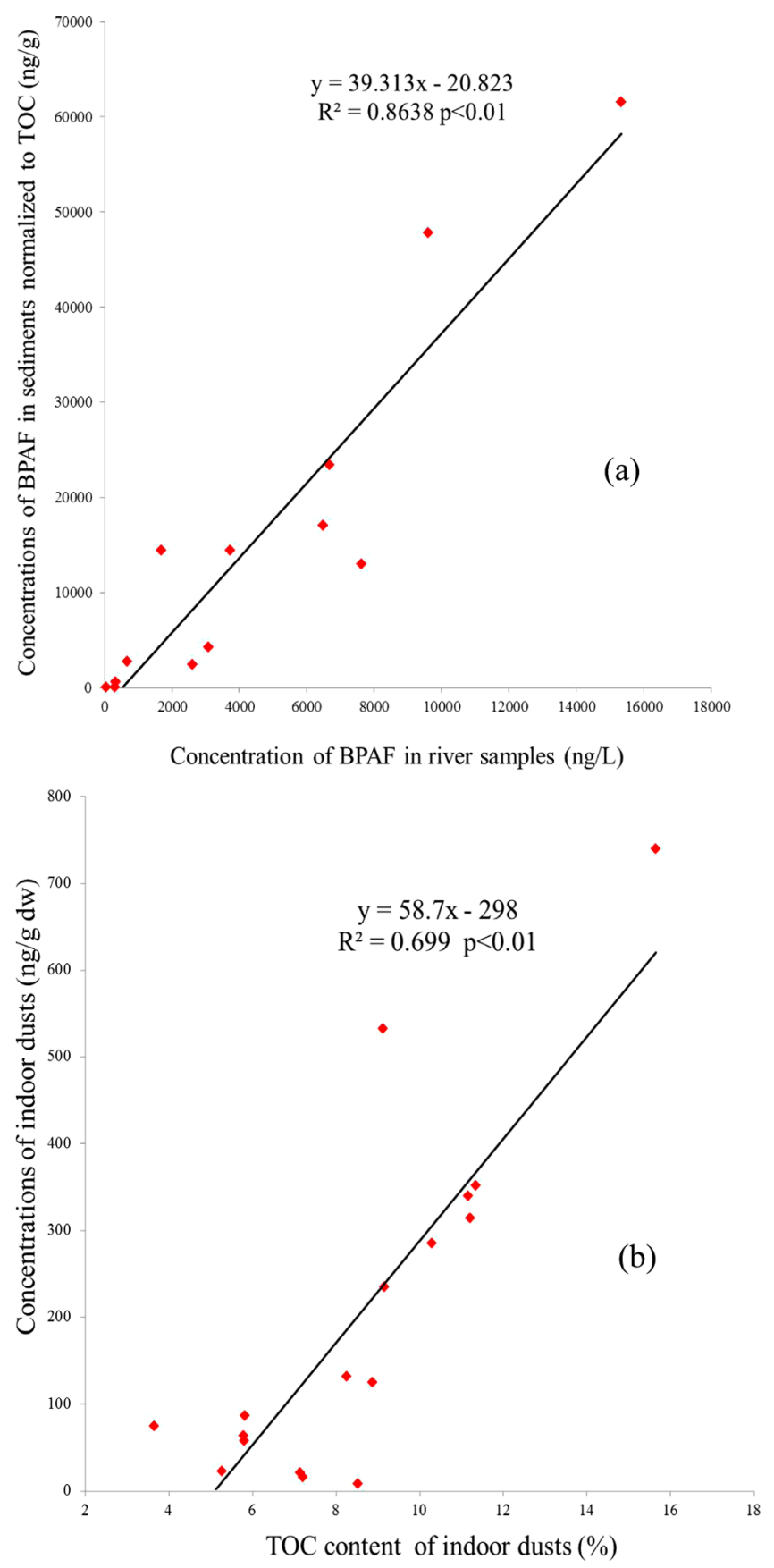

Figure 3. Partition trends of $\operatorname{BPAF}$ (a) between river water and sediment organic carbon (b) in indoor dusts with TOC content.

sediment/water concentration ratio. By using the calculated $K_{\mathrm{oc}}$ value and field sample data, the maximum transport distance of $\mathrm{BPAF}$ along the river can be further investigated by eq $2 .{ }^{37}$

$$
\begin{aligned}
& K_{\mathrm{oc}}=\left(C_{\text {sediments }} / C_{\text {water }}\right) / \text { TOC } \\
& \log \left(C_{0} / C\right)=a+b\left(D / \log K_{\mathrm{oc}}\right)
\end{aligned}
$$

Where $C_{0}(\mathrm{ng} / \mathrm{L})$ is the BPAF concentration in water at the effluent outlet of the plant, $C(\mathrm{ng} / \mathrm{g} \mathrm{dw})$ is the sediment concentration at certain distance $D(\mathrm{~km})$ downstream from the plant, $a$ and $b$ are constants that can be obtained from regression of the field data. Dry weight data were utilized to distinctly investigate the distribution of BPAF in different phases and for TOC calculation. In this work, the a and $b$ 


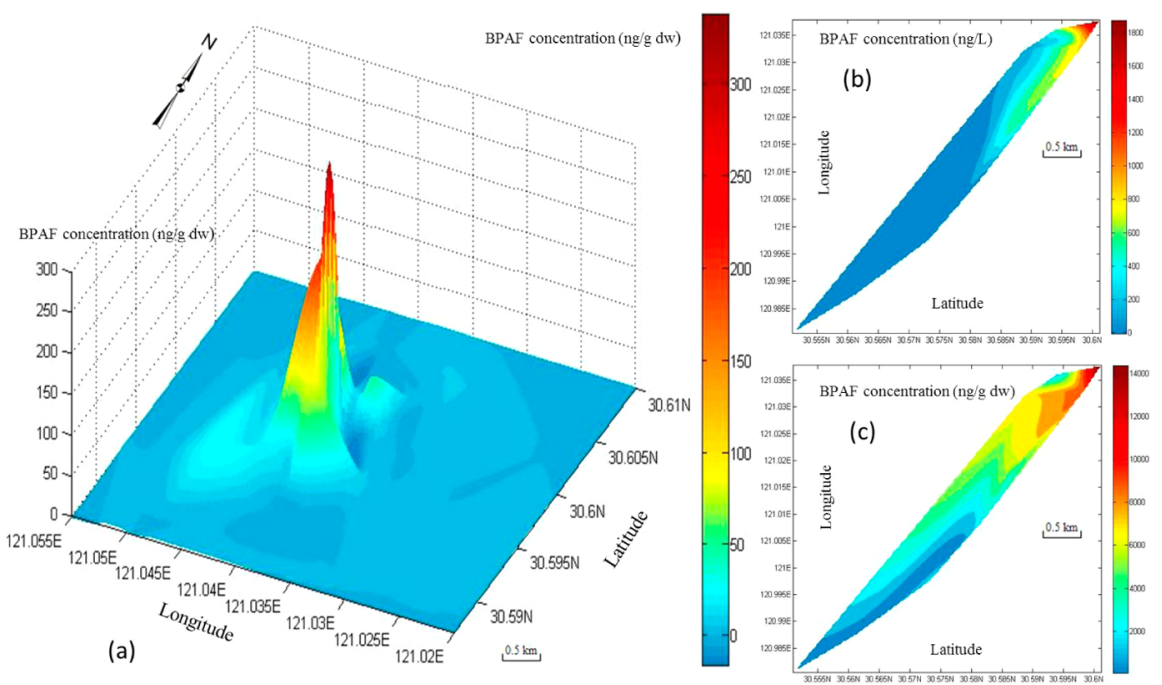

Figure 4. Contour plots of BPAF concentrations in various environmental matrices surrounding the manufacturing plant: (a) in soils, (b) in river water, (c) in sediments.

values were 1.18 and 1.26 by fitting the sample data (BPAF concentration ratios in water/sediment versus distances of sampling locations) according to eq 2 . As $C_{0}$ was $1.53 \times 10^{4}$ $\mathrm{ng} / \mathrm{L}, \log K_{\mathrm{oc}}$ was 3.28 and $\mathrm{C}$ was assumed as MDL $(0.3 \mathrm{ng} / \mathrm{g}$ $\mathrm{dw}$ ) in this study, the calculated maximum transport distance for BPAF was $9.2 \mathrm{~km}$ which suggests within such a distance range $\mathrm{BPAF}$ could still be detected in the investigated river system.

Distribution in Soil Environment. The spatial distribution of BPAF in the soil environment is shown in Figure 4. An exponential declining trend $\left(y=109.07 \times 10^{-0.609 x}, R^{2}=0.81, p\right.$ $<0.01$, SI Figure S1) within several kilometers from the manufacturing plant was also found for the soil samples. From the contour plot, it can be clearly seen that the manufacturing plant was the main contamination source of BPAF to the nearby soil environment. Among the 68 soil samples, $66 \%$ of the samples were located within $2 \mathrm{~km}$ and $69 \%$ of these were all detected for BPAF, while at distances from 2 to $7 \mathrm{~km}$, only 5 of 23 samples contained BPAF above detection limit. The concentrations of BPAF in soils normalized to organic content were from $<$ LOD to $3.67 \times 10^{4} \mathrm{ng} / \mathrm{g}$ TOC. A significant but rather weak linear correlation was found between soil BPAF levels and TOC $\left(R^{2}=0.321, p<0.01\right)$. This could further suggest that organic carbon is an important factor for the transport and fate of BPAF in the environment. To our knowledge, sediments or wastewater treatment plant sludge were not applied to the local agricultural soils in this area. Calculated vapor pressure and Henry's Law constant were respectively $6.98 \times 10^{-5} \mathrm{~Pa}$ and $1.07 \times 10^{-2} \mathrm{~Pa} \cdot \mathrm{m}^{3} / \mathrm{mol}$, which suggest semivolatile properties for BPAF. ${ }^{36}$ The calculated log $K_{\mathrm{oa}}$ of BPAF was 12.1 (EPI suit v4.0, EPA), which suggests that sorption to ambient air particles could be an important transport mechanism of BPAF once released to the atmosphere. This is further supported by a previous multispecies model calculation, where it was found that a large proportion of BPAF would be partitioned to the soil compartment upon release to the air and volatilization from the aquatic environment was a negligible route for the deposition of BPAF to soils. ${ }^{36}$

Local Neighborhood Samples. Tap water and well water are the two major contact water media to the local residents for drinking and domestic uses. To investigate potential contamination of the local waters, the collected 12 tap water and 12 well water samples were analyzed for BPAF. As summarized in SI Table S1, BPAF was detected in 11 out of 12 well water samples with concentrations ranging from 10.0 to $300 \mathrm{ng} / \mathrm{L}$. However, only one tap water sample was found to contain $\mathrm{BPAF}$ at a concentration of $40.0 \mathrm{ng} / \mathrm{L}$. High detection ratio of well water hints that groundwater could be contaminated by BPAF which has been migrated through the river or by atmospheric deposition and subsequent leaching into the lower soil layers. On the opposite, BPAF was barely detected in tap water which means that the source of drinking water in this area was not affected by BPAF contamination and that this drinking source could be from a distant area, or it might be possible that drinking water treatment procedure could effectively eliminate $\mathrm{BPAF}$ residues. It has previously been reported that the chlorination step in the water treatment plants could effectively remove $\mathrm{BPA}^{40}$ This result hinted that drinking water may not be a significant exposure resource for the general local population.

Indoor dust is considered an important exposure source in the residential environment. ${ }^{41}$ All 17 indoor dust samples collected from the local household contained BPAF with concentrations ranging from 15.5 to $739 \mathrm{ng} / \mathrm{g} \mathrm{dw}$. The TOC normalized levels were from 91.8 to $5.83 \times 10^{3} \mathrm{ng} / \mathrm{g}$ TOC, with a median value of $1.47 \times 10^{3} \mathrm{ng} / \mathrm{g}$ TOC. The BPAF concentration in indoor dust is similar with those soil samples at the same distance range $\left(83.3\right.$ to $3.67 \times 10^{4} \mathrm{ng} / \mathrm{g}$ TOC with median value of $1.27 \times 10^{3} \mathrm{ng} / \mathrm{g}$ TOC $)$. A good linear correlation $\left(R^{2}=0.699, p<0.01\right.$, Figure 3$)$ was found between $\mathrm{BPAF}$ and TOC, further in agreement with the suggestion that BPAF is strongly adsorbed to organic carbon. The BPAF levels in dust from this study were relatively higher than that found in a recently published report which found BPAF in indoor dusts from Korea with a geometric mean concentration of $4 \mathrm{ng} / \mathrm{g} .{ }^{13}$ This difference might be explained as samples collected in this work were contaminated by a source point in the local area while samples in Korea were collected from houses, offices, and laboratories in two general cities.

Potential Human Exposure to BPAF. Further research was conducted to investigate the potential exposure of BPAF to 
the local residents living nearby the manufacturing plant. Many exposure pathways have been considered for human exposure assessment such as dietary, ingestion, dermal exposure and inhalation. ${ }^{41-45}$ The results from the environmental samples in the residential area (well water, soil, and indoor dust) were used to evaluate the human exposure to BPAF through three exposure pathways (dermal contact of soils, bathing with well water and inhalation of soils) based on the limited information of local living conditions in this area.

In this study, dermal exposure mainly includes soil contact (indoor dust and outdoor soil) and domestic use of well water for personal cleaning, especially showering/bathing. Estimated daily dermal expose doses (EDDED) of BPAF by soil (DEDs) and bathing $\left(\mathrm{DED}_{\mathrm{b}}\right)$ were both calculated using CSOIL model, which was developed to estimate exposure pathways of organic contaminants and contains comprehensive consideration of different environment media exposures, including soil and groundwater. ${ }^{46}$ The EDDED model is set up according to the following formulas:

$$
\begin{aligned}
\mathrm{EDDED}= & \mathrm{DED}_{\mathrm{s}}+\mathrm{DED}_{\mathrm{b}} \\
\mathrm{DED}_{\mathrm{s}}= & C_{\mathrm{s}} \times \mathrm{AEXP} \times \mathrm{F}_{\mathrm{m}} \times \mathrm{DAE} \times \mathrm{DAR} \times \mathrm{TB} \\
& \times \mathrm{F}_{\mathrm{a}} / \mathrm{BW} \\
\mathrm{DED}_{\mathrm{b}}= & \mathrm{ATOT} \times F_{\mathrm{exp}} \times T_{\mathrm{dc}} \times \mathrm{DAR} \times\left(1-K_{\mathrm{wa}}\right) \times C_{\mathrm{w}} \\
& \times F_{\mathrm{a}} / \mathrm{BW}
\end{aligned}
$$

Where $C_{\mathrm{s}}$ and $C_{\mathrm{w}}$ are BPAF concentrations in soils and bathing water, AEXP is the exposed surface area of skin, $F_{\mathrm{m}}$ is dermal uptake factor, DAE is the degree of skin covered, which means soil mass exposed on a certain skin area, DAR is dermal absorption velocity, TB is period of exposure through soil, $F_{\mathrm{a}}$ is relative absorption factor, (assumed to be 1 in the most severe situation where all BPAF is absorbed into the skin), BW is the body weight, ATOT is the area of body surface, $F_{\exp }$ is fraction of exposed skin during showering, $T_{\mathrm{dc}}$ is showering period, $K_{\mathrm{wa}}$ is the evaporation of the specific compound. Detailed information of the equation parameters, values and units are shown in SI Table S2.

Each of the selected exposure pathways was calculated for adult (7-70 years) and children (1-6 years) separately. All parameters used for calculation were recommended values from RIVM $^{46}$ and based on our experimental results. As shown in

\begin{tabular}{|c|c|c|c|c|}
\hline \multirow[b]{2}{*}{$\begin{array}{c}\text { BPAF } \\
\text { exposure dose } \\
(\mathrm{ng} / \mathrm{kg} * \mathrm{~d})\end{array}$} & \multicolumn{2}{|c|}{ adults } & \multicolumn{2}{|c|}{ children } \\
\hline & exposure dose & $\begin{array}{l}\text { percentage of } \\
\text { total exposure } \\
\text { dose }\end{array}$ & exposure dose & $\begin{array}{l}\text { percentage of } \\
\text { total exposure } \\
\text { dose }\end{array}$ \\
\hline $\begin{array}{l}\text { soil contact } \\
\text { exposure }\end{array}$ & $2.87 \times 10^{-3}$ & $63 \%$ & $13.1 \times 10^{-3}$ & $72 \%$ \\
\hline $\begin{array}{l}\text { bathing } \\
\text { dermal } \\
\text { exposure }\end{array}$ & $0.642 \times 10^{-3}$ & $14 \%$ & $3.17 \times 10^{-3}$ & $18 \%$ \\
\hline $\begin{array}{l}\text { soil inhalation } \\
\text { exposure }\end{array}$ & $1.07 \times 10^{-3}$ & $23 \%$ & $1.79 \times 10^{-3}$ & $10 \%$ \\
\hline $\begin{array}{l}\text { estimated total } \\
\text { exposure } \\
\text { dose }\end{array}$ & $4.58 \times 10^{-3}$ & $100 \%$ & $18.1 \times 10^{-3}$ & $100 \%$ \\
\hline
\end{tabular}
Table 1, the adult exposure doses were calculated to be $2.87 \times$ $10^{-3}$ and $0.642 \times 10^{-3} \mathrm{ng} /(\mathrm{kg} \times \mathrm{d})$ from soil contact and

Table 1. Calculation of BPAF Exposure Dose through the Three Selected Pathways in This Study bathing, respectively, while these were $13.1 \times 10^{-3}$ and $3.17 \times$ $10^{-3} \mathrm{ng} /(\mathrm{kg} \times \mathrm{d})$ for children. These results indicated that soil contact such as soil cultivation and children playing could lead to higher exposure risk to BPAF than the daily use of groundwater for the local residents.

Indoor dusts usually contain high concentrations of various kinds of contaminants due to their high organic carbon content, which could make inhalation an important route of exposure. Thus, inhalation of indoor dust and outdoor soil (both termed together as "soil" in the exposure assessment) may also contribute to exposure of BPAF to the local residents. The calculated $\log \mathrm{K}_{\mathrm{oa}}$ of 12.1 for BPAF also suggested that once released into the atmosphere, most of BPAF would rapidly be partitioned to air particulates, which then could be settled as part of outdoor soil or transported to the indoor environment and settled as part of indoor dust. Based on our results, the Exposure Dose (ED) of BPAF in indoor dust was estimated using the CSOIL model. ${ }^{46}$

$$
\mathrm{ED}_{\text {soil }}=C_{\text {soil }} \times \operatorname{ITSP} \times F_{\mathrm{r}} \times F_{\mathrm{a}} / \mathrm{BW}
$$

ITSP is the inhaled amount of soil particles and $F_{\mathrm{r}}$ is the retention factor soil particles in lungs. According to the results shown in Table 1, the inhalation exposure for adults and children in this area was $1.07 \times 10^{-3}$ and $1.79 \times 10^{-3} \mathrm{ng} /(\mathrm{kg} \times$ day), respectively, using the median concentration under standard dust ingestion situation in the model. ${ }^{46}$ However, other exposure pathways may also have significant contribution on the total exposure dose. In this study, the three routes of exposure; soil contact exposure, bathing dermal exposure and soil inhalation were combined to estimate the total exposure of BPAF from the selected pathways.

$$
\mathrm{ETE}=\mathrm{DED}_{\mathrm{s}}+\mathrm{DED}_{\mathrm{b}}+\mathrm{ED}_{\text {soil }}
$$

The total ETE was about $4.58 \times 10^{-3}$ and $18.1 \times 10^{-3} \mathrm{ng} /$ $(\mathrm{kg} \times$ day) for adults and children, respectively. The contribution of each exposure route is given in Table 1 . Among the three exposure pathways, soil exposure through dermal contact and inhalation accounted for $86 \%$ for adults and $82 \%$ for children. The estimated exposure dose for children was about four times higher than adults. Based on comparison between the three exposure pathways, it was considered that dermal exposure through direct contact with soil was a major nondietary exposure source for both adults and children in this area. As mentioned previously, according to multimedia environmental modeling results, the soil compartment is probably the main depository of BPAF once it is released into the environment. These deductions implied that BPAF contamination in the soil/dust environment is probably the main nondietary source of human exposure in this area. On the other hand, exposure doses are different for adults and children, and children are usually more susceptible for intake of contaminants. ${ }^{47}$ Nevertheless, the importance of BPAF exposure to the local residents should be further corroborated by including more research on other exposure pathways such as dietary intake, ingestion and inhalation.

In this work, the contamination status, transport, and preliminary exposure route assessment of BPAF in various environmental matrices around a manufacturing plant was conducted. The results indicated that sediment and soil could be the major depositories for BPAF once released into the environment due to its strong sorption to organic carbon. It was speculated that exposure to BPAF through dermal contact was the main nondietary exposure pathway between the three 
investigated pathways and children could be more exposed to BPAF through dermal contact with soil, bathing with contaminated water and inhalation of soil. However, dietary intake of BPAF was not assessed as local food samples were not collected and almost no contamination was found in the local drinking water (tap water). More research is therefore needed to further elucidate the total exposure risk and the potential human health effects of BPAF exposure.

\section{ASSOCIATED CONTENT}

\section{S Supporting Information}

Additional information as noted in the text. This material is available free of charge via the Internet at http://pubs.acs.org.

\section{AUTHOR INFORMATION}

\section{Corresponding Author}

*Phone: 8610-6284-9334; fax: 8610-6284-9179; e-mail: gbjiang@rcees.ac.cn.

\section{Notes}

The authors declare no competing financial interest.

\section{ACKNOWLEDGMENTS}

This work was jointly supported by the National Basic Research Program of China (2009CB421605) and the National Natural Science Foundation (20890110, 20621703, 21207140, 21177147). Further support was given by the External Cooperation Program of Chinese Academy of Sciences Grant No.GJHZ1202

\section{REFERENCES}

(1) Temin, S. C. Polymers from bisphenols. Steric inhibition of condensation polymerization 1. J. Org. Chem. 1961, 26 (7), 25182521.

(2) Kitamura, S.; Suzuki, T.; Sanoh, S.; Kohta, R.; Jinno, N.; Sugihara, K.; Yoshihara, S.; Fujimoto, N.; Watanabe, H.; Ohta, S. Comparative study of the endocrine-disrupting activity of bisphenol A and 19 related compounds. Toxicol. Sci. 2005, 84 (2), 249-259.

(3) Patricia, A. H.; Kara, E. K.; Martha, S.; Craig, A. H.; Arlene, I.; Robert, C. V.; Sally, T.; Brian, F. T.; Terry, J. H. Bisphenol A exposure causes meiotic aneuploidy in the female mouse. Curr. Biol. 2003, 13 (7), 546-553.

(4) Yoshihara, S.; Mizutare, T.; Makishima, M.; Suzuki, N.; Fujimoto, N.; Igarashi, K.; Ohta, S. Potent estrogenic metabolites of bisphenol A and bisphenol B formed by rat liver S9 fraction: Their structures and estrogenic potency. Toxicol. Sci. 2004, 78 (1), 50-59.

(5) Rivas, A.; Lacroix, M.; Olea-Serrano, F.; Laios, I.; Leclercq, G.; Olea, N. Estrogenic effect of a series of bisphenol analogues on gene and protein expression in MCF-7 breast cancer cells. J. Steroid. Biochem. 2002, 82 (1), 45-53.

(6) Sui, Y.; Ai, N.; Park, S.-H.; Rios-Pilier, J.; Perkins, J. T.; Welsh, W. J.; Zhou, C. Bisphenol A and its analogues activate human pregnane $\mathrm{X}$ receptor. Environ. Health Perspect. 2012, 120 (3), 399-405.

(7) Cabaton, N.; Dumont, C.; Severin, I.; Perdu, E.; Zalko, D.; Cherkaoui-Malki, M.; Chagnon, M. C. Genotoxic and endocrine activities of bis(hydroxyphenyl)methane (bisphenol F) and its derivatives in the HepG2 cell line. Toxicology 2009, 255 (1-2), 15-24.

(8) Perez, P.; Pulgar, R.; Olea-Serrano, F.; Villalobos, M.; Rivas, A.; Metzler, M.; Pedraza, V.; Olea, N. The estrogenicity of bisphenol Arelated diphenylalkanes with various substituents at the central carbon and the hydroxy groups. Environ. Health Perspect 1998, 106 (3), 167174.

(9) Liao, C.; Kannan, K. High levels of bisphenol a in paper currencies from several countries, and implications for dermal exposure. Environ. Sci. Technol. 2011, 45 (16), 6761-6768.
(10) Vandenberg, Laura N.; Ibrahim, C.; Jerrold, J. H; Vasantha, P.; Francisco, J.R. P.; Schoenfelder, Gilbert Urinary, circulating, and tissue biomonitoring studies indicate widespread exposure to bisphenol A. Environ. Health Perspect 2010, 118 (8), 1055-1070.

(11) Schecter, A.; Malik, N.; Haffner, D.; Smith, S.; Harris, T. R.; Paepke, O.; Birnbaum, L. Bisphenol A (BPA) in U.S. food. Environ. Sci. Technol. 2010, 44 (24), 9425-9430.

(12) Liao, C.; Kannan, K. Widespread occurrence of bisphenol A in paper and paper products: Implications for human exposure. Environ. Sci. Technol. 2011, 45 (21), 9372-9379.

(13) Liao, C.; Liu, F.; Guo, Y.; Moon, H.-B.; Nakata, H.; Wu, Q.; Kannan, $\mathrm{K}$. Occurrence of eight bisphenol analogues in indoor dust from the United States and several Asian Countries: Implications for human exposure. Environ. Sci. Technol. 2012, 46 (16), 9138-9145.

(14) The European Union, Updated European Union Risk Assessment Report: 4,4'-Isopropylidenediphenol(Bisphenol-A): CAS No: 80-05-7, EINECS No:201-245-8, Final Report; European Commission, Office for Official Publications of the European Communities: Luxembourg, 2008.

(15) Environment Canada, Proposed risk management approach for phenol, 4,4'-(1-methylethylidene) bis (Bisphenol A); Environement Canada, Health Canada, 2008.

(16) The 15th announcement of Ministry of Health of P. R. C., 2011. http://www.moh.gov.cn/publicfiles/business/htmlfiles/mohwsjdj/ s7891/201105/51866.htm (accessed May 30, 2011).

(17) Cacho, J. I.; Campillo, N.; Vinas, P.; Hernandez-Cordoba, M. Stir bar sorptive extraction coupled to gas chromatography-mass spectrometry for the determination of bisphenols in canned beverages and filling liquids of canned vegetables. J. Chromatogr., A 2012, 1247, 146-153.

(18) Fromme, H.; Kuchler, T.; Otto, T.; Pilz, K.; Muller, J.; Wenzel, A. Occurrence of phthalates and bisphenol $A$ and $F$ in the environment. Water Res. 2002, 36 (6), 1429-1438.

(19) Grumetto, L.; Montesano, D.; Seccia, S.; Albrizio, S.; Barbato, F. Determination of bisphenol A and bisphenol B residues in canned peeled tomatoes by reversed-phase liquid chromatography. J. Agric. Food. Chem. 2008, 56 (22), 10633-10637.

(20) Cunha, S. C.; Almeida, C.; Mendes, E.; Fernandes, J. O. Simultaneous determination of bisphenol $\mathrm{A}$ and bisphenol $\mathrm{B}$ in beverages and powdered infant formula by dispersive liquid-liquid micro-extraction and heart-cutting multidimensional gas chromatography-mass spectrometry. Food Addit. Contam. A 2011, 28 (4), 513526.

(21) Cunha, S. C.; Fernandes, J. O. Quantification of free and total bisphenol $\mathrm{A}$ and bisphenol $\mathrm{B}$ in human urine by dispersive liquidliquid microextraction (DLLME) and heart-cutting multidimensional gas chromatography-mass spectrometry (MD-GC/MS). Talanta. 2010, 83 (1), 117-25.

(22) Cobellis, L.; Colacurci, N.; Trabucco, E.; Carpentiero, C.; Grumetto, L. Measurement of bisphenol A and bisphenol B levels in human blood sera from endometriotic women. Biomed. Chromatogr. 2009, 23 (11), 1186-1190.

(23) Liao, C.; Liu, F.; Kannan, K. Bisphenol S, a new bisphenol analogue, in paper products and currency bills and its association with bisphenol A residues. Environ. Sci. Technol. 2012, 46 (12), 6515-6522.

(24) Liao, C.; Liu, F.; Alomirah, H.; Loi, V. D.; Mohd, M. A.; Moon, H.-B.; Nakata, H.; Kannan, K. Bisphenol $\mathrm{S}$ in urine from the united states and seven asian countries: occurrence and human exposures. Environ. Sci. Technol. 2012, 46 (12), 6860-6866.

(25) Konno, Y.; Suzuki, H.; Kudo, H.; Kameyama, A.; Nishikubo, T. Synthesis and properties of fluorine-containing poly(ether)s with pendant hydroxyl groups by the polyaddition of bis(oxetane)s and bisphenol AF. Polym. J. 2004, 36 (2), 114-122.

(26) Baradie, B.; Shoichet, M. S. Novel fluoro-terpolymers for coatings applications. Macromolecules 2005, 38 (13), 5560-5568.

(27) Schonberger, F.; Chromik, A.; Kerres, J. Synthesis and characterization of novel (sulfonated) poly(arylene ether)s with pendent trifluoromethyl groups. Polymer 2009, 50 (9), 2010-2024. 
(28) National Toxicology Program concept: BPAF. http://ntp.niehs. nih.gov/files/BPAF_Concept_final-100608_508.pdf (accessable in November 2008).

(29) Mao, M.; Das, S.; Turner, S. R. Synthesis and characterization of poly(aryl ether sulfone) copolymers containing terphenyl groups in the backbone. Polymer 2007, 48 (21), 6241-6245.

(30) Li, Y.; Burns, K. A.; Arao, Y.; Luh, C. J.; Korach, K. S. Differential estrogenic actions of endocrine-disrupting chemicals bisphenol A, bisphenol AF, and zearalenone through estrogen receptor alpha and beta in vitro. Environ. Health Perspect 2012, 120 (7), 10291035.

(31) Lee, S.; Kim Y. K.; Shin T. Y.; Kim S. H., Neurotoxic effects of bisphenol AF on calcium-induced ROS and MAPKs. Neurotox Res. Published online: 21 september 2012.

(32) Matsushima, A.; Liu, X.; Okada, H.; Shimohigashi, M.; Shimohigashi, Y. Bisphenol AF Is a full agonist for the estrogen receptor ER alpha but a highly specific antagonist for ER beta. Environ. Health Perspect 2010, 118 (9), 1267-1272.

(33) Feng, Y.; Yin, J.; Jiao, Z.; Shi, J.; Li, M.; Shao, B. Bisphenol AF may cause testosterone reduction by directly affecting testis function in adult male rats. Toxicol. Lett. 2012, 211 (2), 201-209.

(34) Zhejiang Norchain Technology Development Co., Ltd. Home Page. http://www.norchain-tech.com/index.php/Index/index/lang/ 1\%2Findex\%2Flang\%2F1\%2F/ (accessed on August 30, 2009).

(35) Qiu, X.; Hites, R. A. Dechlorane Plus and other flame retardants in tree bark from the northeastern United States. Environ. Sci. Technol. 2008, 42 (1), 31-36.

(36) Environment Canada, Screening Assessment for the ChallengePhosphonium, triphenyl(phenylmethyl)-, salt with 4,4'-[2,2,2-trifluoro-1(trifluoromethyl)ethylidene]bis[phenol] (1:1); Environmental Canada, Health Canada, 2010.

(37) Lopez-Avila, V.; Hites, R. A. Organic compounds in an industrial wastewater. Their transport into sediments. Environ. Sci. Technol. 1980, 14 (11), 1382-1390.

(38) Gregory, A. J.; Lopez-Avila, V.; Hites, R. A. Organic compounds in an industrial wastewater: A case study of their environmental impact. Environ. Sci. Technol. 1978, 12 (1), 88-96.

(39) Schwarzenbach, R. P.; Gschwend, P. M.; Imboden, D. M. Environmental Organic Chemistry; Wiley: New York, Chichester, Brisbane, Toronto, Singapore, 2003.

(40) Hu, J. Y.; Aizawa, T.; Ookubo, S. Products of aqueous chlorination of bisphenol A and their estrogenic activity. Environ. Sci. Technol. 2002, 36 (9), 1980-1987.

(41) Strynar, M. J.; Lindstrom, A. B. Perfluorinated compounds in house dust from Ohio and North Carolina, USA. Environ. Sci. Technol. 2008, 42 (10), 3751-3756.

(42) Belsey, N. A.; Cordery, S. F.; Bunge, A. L.; Guy, R. H. Assessment of dermal exposure to pesticide residues during re-entry. Environ. Sci. Technol. 2011, 45 (10), 4609-4615.

(43) Vom Saal, F. S.; Hughes, C. An extensive new literature concerning low-dose effects of bisphenol A shows the need for a new risk assessment. Environ. Health Perspect 2005, 113 (8), 926-933.

(44) Zhang, T.; Sun, H. W.; Wu, Q.; Zhang, X. Z.; Yun, S. H.; Kannan, K. Perfluorochemicals in meat, eggs and indoor dust in China: Assessment of sources and pathways of human exposure to perfluorochemicals. Environ. Sci. Technol. 2010, 44 (9), 3572-3579.

(45) Fraser, A. J.; Webster, T. F.; McClean, M. D. Diet contributes significantly to the body burden of PBDEs in the general U.S. population. Environ. Health. Perspect. 2009, 117 (10), 1520-1525.

(46) Brand, E.; P. F. O., Lijzen, J.P.A., CSOIL 2000: an exposure model for human risk assessment of soil contamination A model description; The National Institute for Public Health and the Environment (RIVM), Dutch, 2007.

(47) Schets, F. M.; Schijven, J. F.; de Roda Husman, A. M. Exposure assessment for swimmers in bathing waters and swimming pools. Water Res. 2011, 45 (7), 2392-2400. 